\title{
Quantitative trait loci identified for blood chemistry components of an advanced intercross line of chickens under heat stress

Angelica Van Goor ${ }^{1}$, Christopher M. Ashwell², Michael E. Persia ${ }^{3}$, Max F. Rothschild ${ }^{1}$, Carl J. Schmidt ${ }^{4}$ and Susan J. Lamont ${ }^{*}$

\begin{abstract}
Background: Heat stress in poultry results in considerable economic losses and is a concern for both animal health and welfare. Physiological changes occur during periods of heat stress, including changes in blood chemistry components. A highly advanced intercross line, created from a broiler (heat susceptible) by Fayoumi (heat resistant) cross, was exposed to daily heat cycles for seven days starting at 22 days of age. Blood components measured pre-heat treatment and on the seventh day of heat treatment included $\mathrm{pH}, \mathrm{pCO}_{2}, \mathrm{pO}_{2}$, base excess, $\mathrm{HCO}_{3}, \mathrm{TCO}_{2}, \mathrm{~K}, \mathrm{Na}$, ionized $\mathrm{Ca}$, hematocrit, hemoglobin, $\mathrm{sO}_{2}$, and glucose. A genome-wide association study (GWAS) for these traits and their calculated changes was conducted to identify quantitative trait loci (QTL) using a $600 \mathrm{~K}$ SNP panel.
\end{abstract}

Results: There were significant increases in $\mathrm{pH}$, base excess, $\mathrm{HCO}_{3}, \mathrm{TCO}_{2}$, ionized $\mathrm{Ca}$, hematocrit, hemoglobin, and $\mathrm{sO}_{2}$, and significant decreases in $\mathrm{pCO}_{2}$ and glucose after 7 days of heat treatment. Heritabilities ranged from 0.01-0.21 for pre-heat measurements, 0.01-0.23 for measurements taken during heat, and 0.00-0.10 for the calculated change due to heat treatment. All blood components were highly correlated within measurement days, but not correlated between measurement days. The GWAS revealed 61 QTL for all traits, located on GGA (Gallus gallus chromosome) 1, 3, 6, 9, 10, 12-14, 17, 18, 21-28, and Z. A functional analysis of the genes in these QTL regions identified the Angiopoietin pathway as significant. The QTL that co-localized for three or more traits were on GGA10,22, 26, 28, and $Z$ and revealed candidate genes for birds' response to heat stress.

Conclusions: The results of this study contribute to our knowledge of levels and heritabilities of several blood components of chickens under thermoneutral and heat stress conditions. Most components responded to heat treatment. Mapped QTL may serve as markers for genomic selection to enhance heat tolerance in poultry. The Angiopoietin pathway is likely involved in the response to heat stress in chickens. Several candidate genes were identified, giving additional insight into potential mechanisms of physiologic response to high ambient temperatures.

\section{Background}

Climate change has increased the frequency of severe heat waves and the global temperature is projected to become increasingly warmer [1]. Heat stress in poultry negatively impacts animal production and welfare resulting in economic losses estimated to be between \$125-165 million for the U.S. broiler poultry industry [2]. During a severe heat wave in Iowa, over 1.5 million layer hens died [3].

\footnotetext{
* Correspondence: sjlamont@iastate.edu

'Department of Animal Science, lowa State University, Ames, IA, USA

Full list of author information is available at the end of the article
}

To reduce core body temperature during periods of heat stress, blood flow to internal organs decreases and blood flow to the combs and other surface tissues increases in chickens [4]. During periods of heat stress, blood volume and oxygen carrying capacity are altered [5] and dehydration, caused by increased respiration, can increase hematocrit [6]. Energy availability, as determined by plasma glucose level, is increased in chickens exposed to heat stress [7].

During high ambient temperatures, chickens reduce feed intake by as much as $17 \%$, which reduces growth [8]. However, metabolic and endocrine changes during 
heat stress also contribute to reduction in growth in broilers, as demonstrated by a pair-feeding study [9].

A major change in blood components is caused by heat-induced increased respiration, which results in respiratory alkalosis, a disturbance in the acid base balance characterized by an increase in blood $\mathrm{pH}$ accompanied by a decrease in $\mathrm{pCO}_{2}$. Respiratory alkalosis occurs in broilers during heat stress and is associated with reduced growth rate [10]. Metabolic alkalosis is an additional measure of disturbances in acid base balance and is defined by a decrease in the fixed acid concentrations and an increase in fixed base concentrations within the extracellular fluid [11].

Electrolyte balance is essential for acid base balance, maintenance of cellular homeostasis, synthesis of tissue protein, electrical potential of cell membranes, enzymatic reactions, and maintaining osmotic pressure [12]. Altering electrolyte amounts in feed partially ameliorates the negative impacts of heat stress in broiler chickens [13].

The goal of the current study was to identify the physiological changes and genomic regions associated with response to heat stress in chickens as characterized by the blood chemistry components, including $\mathrm{pH}$, $\mathrm{pCO}_{2}, \mathrm{pO}_{2}$, base excess (BE), $\mathrm{HCO}_{3}, \mathrm{TCO}_{2}, \mathrm{~K}, \mathrm{Na}$, ionized $\mathrm{Ca}(\mathrm{iCa})$, hematocrit (Hct), hemoglobin $(\mathrm{Hb}), \mathrm{sO}_{2}$, and glucose (Glu). In a commercial egg laying population, developmental measures have been established with hopes of using measures of blood chemistry components for selection [14]. To date, few studies have identified quantitative trait loci (QTL) for blood components in chicken [15-18]. We used a $600 \mathrm{~K}$ SNP panel to identify QTL regions associated with levels of blood components of chickens under thermoneutral and heat stress conditions, and changes induced by heat.

\section{Results}

\section{Blood component measurements and heritabilities}

Phenotypic means and heritabilities are given in Table 1 for blood components measured pre-heat (day 20 of age), after 7 days of heat treatment (day 28 of age), and the calculated change due to heat treatment (day 2820). After 7 days of heat treatment, $\mathrm{pH}, \mathrm{BE}, \mathrm{HCO}_{3}$, $\mathrm{TCO}_{2}, \mathrm{iCa}, \mathrm{Hct}, \mathrm{Hb}$, and $\mathrm{sO}_{2}$ significantly increased while $\mathrm{pCO}_{2}$ and glucose significantly decreased. There were no significant changes in $\mathrm{pO}_{2}, \mathrm{~K}$, and $\mathrm{Na}$ due to heat treatment.

Heritabilities ranged from $0.01-0.21$ for pre-heat measurements, 0.01-0.23 for measurements taken during heat, and 0.00-0.10 for the calculated change due to heat treatment.

\section{Trait correlations}

Correlations between blood components at each measurement phase are given in Fig. 1 as a heat map. Almost all blood components were positively correlated with all other variables measured on the same day. Very few significant correlations, however, occurred between variables measured on different days.

\section{Genotyping}

Of the 480 genotyped birds, 458 Advanced Intercross Line (AIL) and all 12 parental line birds passed the whole animal DishQC criterion. Of the 580,961 SNPs on the array, filtering based on SNP call rate $\geq 95 \%$ removed a small proportion (59,789 SNPs), whereas filtering based on MAF removed a much larger proportion (311,055 SNPs), yielding 210,117 SNPs for subsequent analyses.

\section{GWAS}

The results from the GWAS for each trait are depicted in Fig. 2. A wide range of genetic variation (0.5-9.8 \%) was explained by each significant window and detailed information is found in Table 2. Adjacent windows that were significant for a single trait are discussed below as a single QTL region.

Six QTL for $\mathrm{pH}$ phenotypes were identified: three for pH20 with two on GGA18 and one on GGA28, one for pH28 on GGA12, and two for pH28-20 with one each on GGA6 and GGA10.

Nine QTL for $\mathrm{pCO}_{2}$ measurements were identified: one for $\mathrm{pCO}_{2} 20$ on GGA28, four for $\mathrm{pCO}_{2} 28$ located on GGA1, 9, 10, and 27, and four for $\mathrm{pCO}_{2} 28-20$ on GGA3, 10,23 , and 28. No QTL were identified for $\mathrm{pO}_{2} 20$ or for $\mathrm{pO}_{2} 28-20$. One QTL was identified for $\mathrm{pO}_{2} 28$ on GGA13.

A total of five QTL were identified for BE traits: two for BE20 on GGA18, three for BE28 with one each on GGA1, 21, and 27, and none for BE28-20. Nine QTL were identified for $\mathrm{TCO}_{2}$ traits: none for $\mathrm{TCO}_{2} 20$; eight for $\mathrm{TCO}_{2} 28$ one each on GGA6 and GGA26, and six on GGAZ, and one for $\mathrm{TCO}_{2} 28-20$ on GGA10. No QTL were identified for $\mathrm{HCO}_{3} 20$ or $\mathrm{HCO}_{3} 28-20$, while seven were revealed for $\mathrm{HCO}_{3} 28$ with one on GGA6 and six on GGAZ.

Five QTL for $\mathrm{K}$ traits were identified: four for K20 with two on GGA10, one on GGA12, and one on GGA26, none for K28 and one for K28-20 located on GGA12. No QTL were identified for the Na phenotypes. A single QTL was identified for ionized Ca phenotypes: for $\mathrm{iCa} 28$ on GGA26.

We identified five QTL for Hct measurements: none for Hct20 or Hct28-20, and five for Hct28 located one each on GGA1, 10, 14, 22, and two on GGA28. Seven QTL were identified for $\mathrm{Hb}$ : none for $\mathrm{Hb} 20$, six for Hb28 located one each on GGA1, 10, 14, 22, and two on 28, and one for $\mathrm{Hb} 28-20$ on GGA22. There were three QTL for $\mathrm{sO}_{2}$ phenotypes: none for $\mathrm{sO}_{2} 20$, two for $\mathrm{sO}_{2} 28$ located on GGA24 and GGA25, and one for $\mathrm{sO}_{2} 28-20$ on GGA17. 
Table 1 Phenotypic means and heritabilities $\left(h^{2}\right)$

\begin{tabular}{|c|c|c|c|c|c|c|}
\hline \multirow[t]{2}{*}{ Trait } & \multicolumn{2}{|l|}{ Day 20} & \multicolumn{2}{|l|}{ Day 28} & \multicolumn{2}{|l|}{ Day $28-20$} \\
\hline & $\overline{M e a n} \pm$ SEM & $h^{2}(S E)$ & $\overline{M e a n} \pm$ SEM & $h^{2}(S E)$ & $\overline{M e a n} \pm$ SEM & $h^{2}(S E)$ \\
\hline $\mathrm{pH}$ & $7.50 \pm 0.0^{a}$ & $.17(0.08)$ & $7.53 \pm 0.003^{b}$ & $.10(0.08)$ & $0.03 \pm 0.004$ & $.05(0.03)$ \\
\hline $\mathrm{pCO}_{2}, \mathrm{mmHg}$ & $31.9 \pm 0.1^{\mathrm{a}}$ & $.21(0.06)$ & $31.1 \pm 0.2^{b}$ & $.05(0.04)$ & $-0.8 \pm 0.2$ & $.07(0.05)$ \\
\hline $\mathrm{pO}_{2}, \mathrm{mmHg}$ & $43.3 \pm 0.3^{a}$ & $.06(0.04)$ & $43.9 \pm 0.2^{\mathrm{a}}$ & $.05(0.05)$ & $0.5 \pm 0.3$ & $.00(0.03)$ \\
\hline $\mathrm{BE}, \mathrm{mM}$ & $1.8 \pm 0.1^{a}$ & $.10(0.05)$ & $3.3 \pm 0.2^{b}$ & $.02(0.02)$ & $1.5 \pm 0.2$ & $.00(0.02)$ \\
\hline $\mathrm{HCO}_{3}, \mathrm{mM}$ & $25.0 \pm 0.1^{a}$ & $.05(0.04)$ & $26.0 \pm 0.1^{b}$ & $.23(0.12)$ & $1.0 \pm 0.2$ & $.03(0.02)$ \\
\hline $\mathrm{TCO}_{2}, \mathrm{mM}$ & $25.9 \pm 0.1^{\mathrm{a}}$ & $.02(0.03)$ & $26.9 \pm 0.1^{b}$ & $.13(0.09)$ & $1.0 \pm 0.2$ & $.01(0.01)$ \\
\hline $\mathrm{K}, \mathrm{mM}$ & $4.8 \pm 0.0^{\mathrm{a}}$ & $.20(0.01)$ & $4.9 \pm 0.0^{\mathrm{a}}$ & $.02(0.01)$ & $0.1 \pm 0.0$ & $.10(0.06)$ \\
\hline $\mathrm{Na}, \mathrm{mM}$ & $137.0 \pm 0.2^{\mathrm{a}}$ & $.08(0.6)$ & $137.2 \pm 0.3^{\mathrm{a}}$ & $.01(0.01)$ & $0.3 \pm 0.3$ & $.01(0.01)$ \\
\hline iCa, mM & $1.25 \pm 0.0^{\mathrm{a}}$ & $.04(0.01)$ & $1.28 \pm 0.01^{b}$ & $.02(0.01)$ & $0.02 \pm 0.01$ & $.01(0.01)$ \\
\hline $\mathrm{Hct}, \%$ PCV & $22.5 \pm 0.2^{a}$ & $.01(0.03)$ & $23.2 \pm 0.1^{b}$ & $.21(0.08)$ & $0.7 \pm 0.2$ & $.02(0.01)$ \\
\hline $\mathrm{Hb}, \mathrm{g} / \mathrm{dL}$ & $7.7 \pm 0.1^{\mathrm{a}}$ & $.07(0.05)$ & $7.9 \pm 0.0^{b}$ & $.11(0.04)$ & $0.2 \pm 0.1$ & $.02(0.01)$ \\
\hline $\mathrm{sO}_{2}, \%$ & $83.2 \pm 0.2^{a}$ & $.03(0.05)$ & $84.7 \pm 0.2^{b}$ & $.02(0.02)$ & $1.5 \pm 0.3$ & $.01(0.01)$ \\
\hline Glu, mg/dl & $252 \pm 0.8^{a}$ & $.15(0.08)$ & $243 \pm 1^{b}$ & $.19(0.09)$ & $-8 \pm 1$ & $.02(0.02)$ \\
\hline
\end{tabular}

Blood chemistry components were measured pre-heat (day 20), on the seventh day of heat treatment (day 28), and the calculated change due to heat (day $28-$ 20). Different superscript letters within row represent significant differences $(P \leq 0.05)$

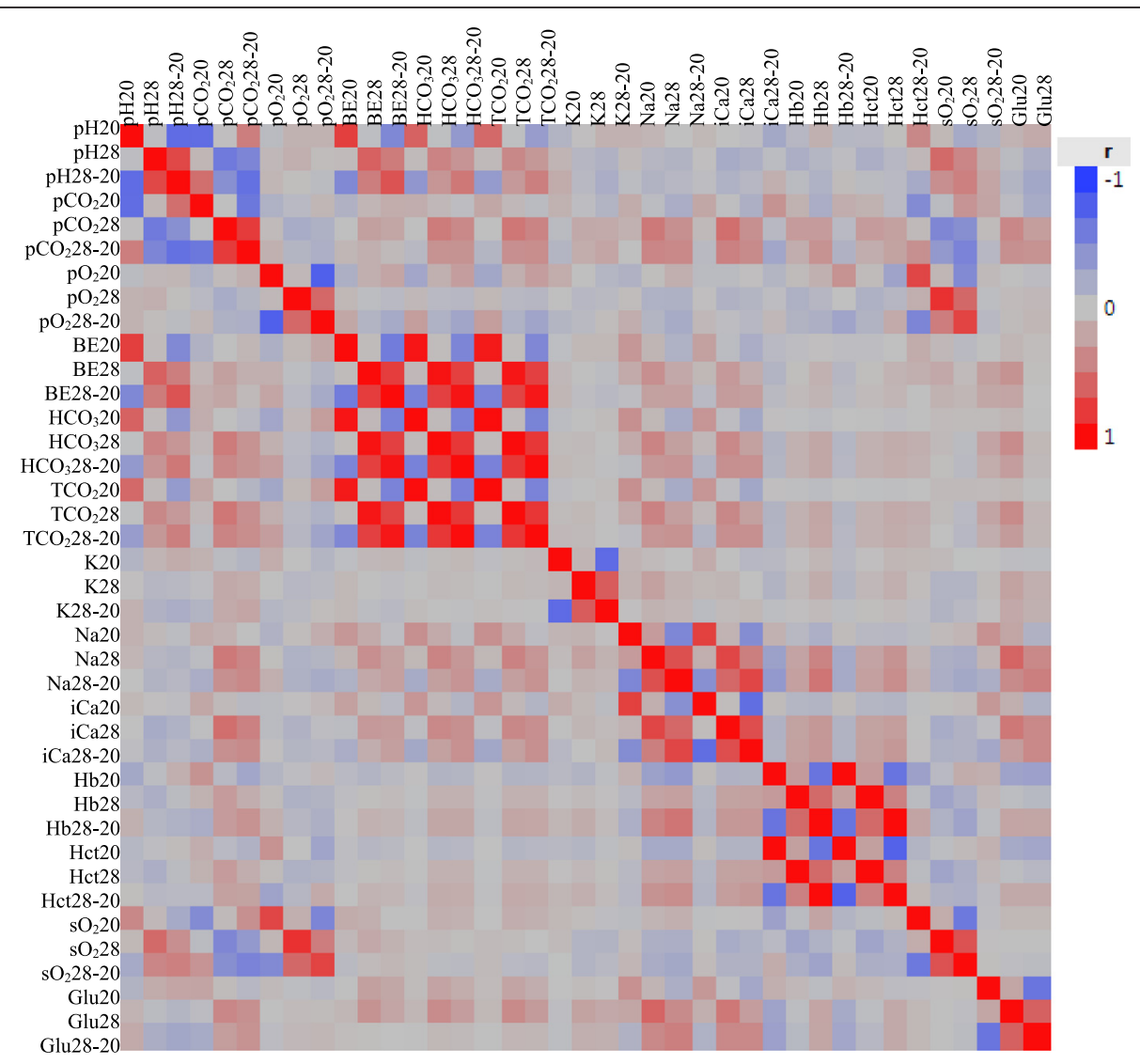

Fig. 1 Heat map of phenotypic correlations between blood chemistry components. Heat map showing phenotypic correlations between blood chemistry components measured on day 20 (pre-heat), day 28 (during heat), and day 28-20 which is the difference due to heat treatment. Traits are clustered together based on function. The colors represent the correlation coefficient $\left(r^{2}\right)$ with red indicating a positive correlation and blue indicating a negative correlation 


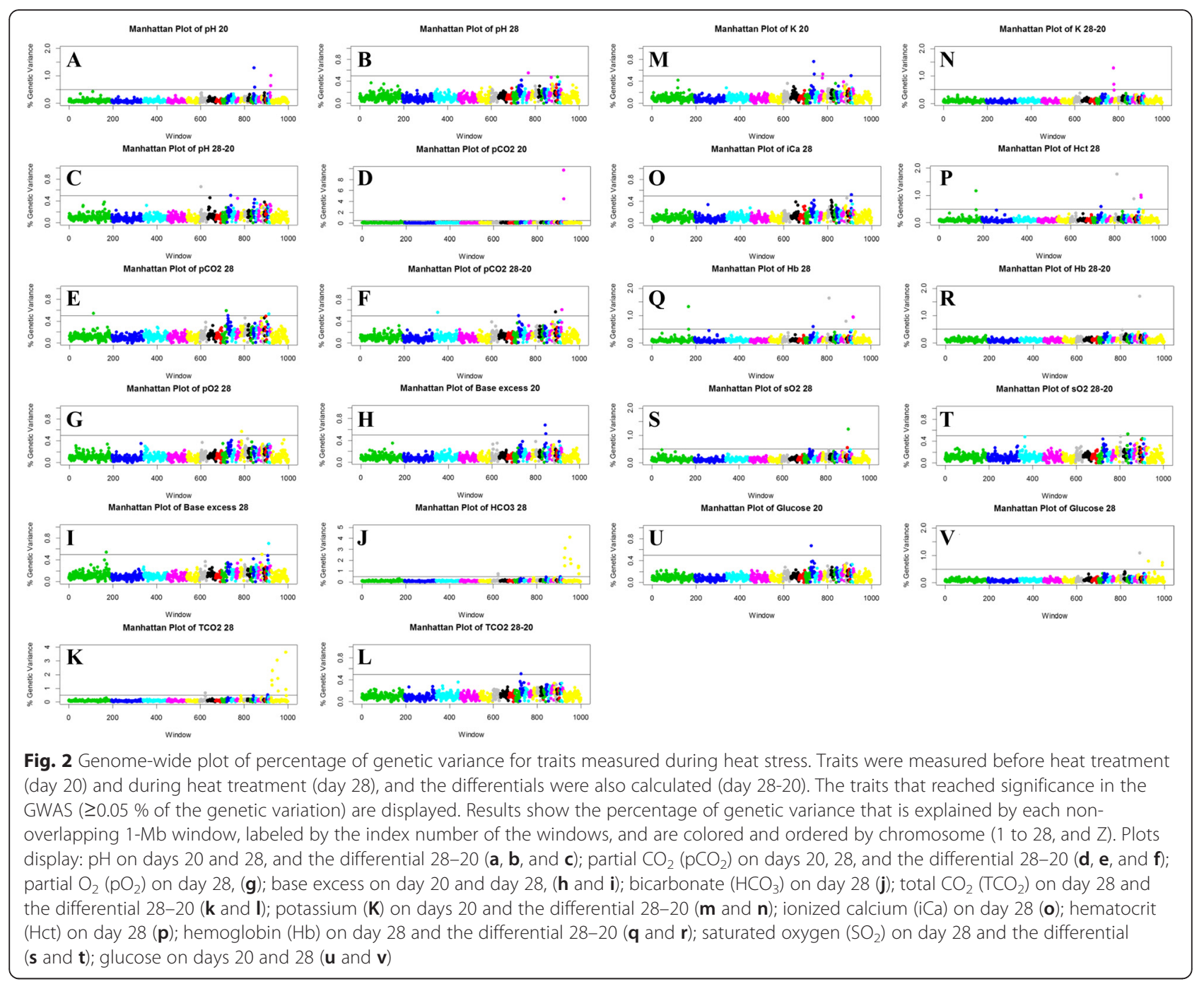

Four QTL were identified for Glu: one for Glu20 on GGA10, and three for Glu28 with one on GGA22 and two on GGAZ.

\section{Pathway analysis}

The pathway analysis of all annotated genes within significant QTL regions across all measured traits, and separately for genes in the regions of QTL co-localization, and the top 20 significant $(P \leq 0.05)$ canonical pathways for each group are listed in Table 3. Of the 999 genes identified within all significant QTL regions, 682 genes were annotated within IPA and used for the pathway analysis. Two canonical pathways of interest for all identified QTL include the AMPK signalling and Angiopoietin signalling pathways. Of the 226 genes in regions of QTL co-localization, 185 were annotated within IPA and used for pathway analysis. A pathway of particular interest that was revealed was the Cardiac Hypertrophy signalling pathway.

\section{Candidate genes}

We explored regions of QTL co-localization in detail to identify candidate genes that may give insight into the complex biological mechanisms that control blood component response to heat stress. Candidate genes were identified using Ensemble Biomart within the $1 \mathrm{Mb}$ windows that were significant for 3 or more traits (Additional file 1: Table S1).

\section{Discussion}

The aim of this study was to identify and estimate the effect of QTL, and to perform a functional analysis using positional candidate genes, for blood components $(\mathrm{pH}$, $\mathrm{pCO}_{2}, \mathrm{pO}_{2}$, base excess, $\mathrm{HCO}_{3}, \mathrm{TCO}_{2}, \mathrm{~K}, \mathrm{Na}$, ionized $\mathrm{Ca}$, $\mathrm{Hct}, \mathrm{Hb}, \mathrm{sO}_{2}$, and Glu) using a novel AIL of chickens under heat stress and a $600 \mathrm{~K} \mathrm{SNP}$ panel for genotyping. The blood components measured were within the accepted range reported for chicken [19]. Blood chemistry components are grouped into functional categories (i.e., 
Table 2 Windows explaining a significant percentage $(\geq 0.5)$ of genetic variance

\begin{tabular}{|c|c|c|c|c|c|c|c|c|c|}
\hline \multicolumn{6}{|c|}{ Windows explaining $\geq 0.5 \%$ of genetic variance } & \multicolumn{4}{|c|}{ SNP with highest model frequency within window } \\
\hline Trait $^{\mathrm{a}}$ & Chr & Pos (Mb) & $\begin{array}{l}\% \text { of genetic } \\
\text { variance explained }\end{array}$ & $\mathrm{Nb}$ of SNPS & $\begin{array}{l}\text { Freq of iterations } \\
\text { with }(P>0)^{\mathrm{b}}\end{array}$ & SNP name & SNP pos (bp) & Model freq $^{e}$ & Allele freq \\
\hline $\mathrm{pH} 20$ & 18 & 3 & 1.29 & 401 & 0.94 & AX-75894740 & 3342614 & 0.0111 & 0.652 \\
\hline $\mathrm{pH} 2 \mathrm{O}$ & 28 & 4 & 1.01 & 328 & 0.85 & AX-76384843 & 4097788 & 0.0090 & 0.294 \\
\hline $\mathrm{pH} 2 \mathrm{O}$ & 28 & 3 & 0.64 & 437 & 0.92 & AX-76383580 & 3856132 & 0.0092 & 0.294 \\
\hline $\mathrm{pH} 2 \mathrm{O}$ & 18 & 6 & 0.58 & 342 & 0.86 & AX-75894671 & 6670745 & 0.0075 & 0.340 \\
\hline $\mathrm{pH} 28$ & 12 & 7 & 0.55 & 302 & 0.81 & AX-75723368 & 7630857 & 0.0070 & 0.288 \\
\hline $\mathrm{pH} 28-20$ & 6 & 4 & 0.66 & 350 & 0.86 & AX-76958371 & 4259110 & 0.0074 & 0.724 \\
\hline $\mathrm{pH} 28-20$ & 10 & 16 & 0.50 & 372 & 0.89 & AX-75591175 & 16460945 & 0.0066 & 0.298 \\
\hline $\mathrm{pCO}_{2} 20$ & 28 & 3 & 9.75 & 437 & 0.93 & AX-76383461 & 3835952 & 0.0448 & 0.711 \\
\hline $\mathrm{pCO}_{2} 20$ & 28 & 4 & 4.49 & 328 & 0.89 & AX-76385219 & 4167579 & 0.0239 & 0.706 \\
\hline $\mathrm{pCO}_{2} 28$ & 9 & 20 & 0.59 & 462 & 0.94 & AX-75706074 & 19358758 & 0.0070 & 0.416 \\
\hline $\mathrm{pCO}_{2} 28$ & 1 & 110 & 0.54 & 194 & 0.38 & AX-80866127 & 110487208 & 0.0098 & 0.510 \\
\hline $\mathrm{pCO}_{2} 28$ & 27 & 2 & 0.53 & 650 & 0.96 & AX-76356017 & 2038872 & 0.0065 & 0.653 \\
\hline $\mathrm{pCO}_{2} 28$ & 10 & 3 & 0.50 & 447 & 0.91 & AX-75607032 & 3037730 & 0.0069 & 0.626 \\
\hline $\mathrm{pCO}_{2} 28-20$ & 28 & 4 & 0.61 & 328 & 0.83 & AX-76384843 & 4097788 & 0.0076 & 0.296 \\
\hline $\mathrm{pCO}_{2} 28-20$ & 23 & 2 & 0.57 & 388 & 0.86 & AX-76282215 & 2594470 & 0.0071 & 0.435 \\
\hline $\mathrm{pCO}_{2} 28-20$ & 3 & 14 & 0.56 & 287 & 0.81 & AX-76421954 & 14679413 & 0.0075 & 0.323 \\
\hline $\mathrm{pCO}_{2} 28-20$ & 10 & 1 & 0.50 & 393 & 0.86 & AX-75601081 & 1816619 & 0.0080 & 0.339 \\
\hline $\mathrm{pO}_{2} 28$ & 13 & 5 & 0.57 & 277 & 0.79 & AX-75758019 & 5130673 & 0.0070 & 0.531 \\
\hline BE20 & 18 & 3 & 0.68 & 401 & 0.93 & AX-75894740 & 3342614 & 0.0103 & 0.652 \\
\hline BE20 & 18 & 6 & 0.52 & 342 & 0.84 & AX-75906711 & 6859485 & 0.0078 & 0.554 \\
\hline BE28 & 27 & 2 & 0.70 & 650 & 0.97 & AX-76359325 & 2733806 & 0.0076 & 0.473 \\
\hline BE28 & 1 & 172 & 0.54 & 202 & 0.67 & AX-75342016 & 172010216 & 0.0094 & 0.683 \\
\hline BE28 & 21 & 4 & 0.50 & 521 & 0.91 & AX-76247040 & 4491122 & 0.0078 & 0.321 \\
\hline $\mathrm{HCO}_{3} 28$ & Z & 30 & 4.11 & 74 & 0.47 & AX-77209983 & 30284984 & 0.1864 & 0.671 \\
\hline $\mathrm{HCO}_{3} 28$ & Z & 8 & 3.10 & 24 & 0.27 & AX-80958477 & 8485438 & 0.0719 & 0.357 \\
\hline $\mathrm{HCO}_{3} 28$ & Z & 5 & 2.22 & 62 & 0.33 & AX-80834191 & 5042699 & 0.0931 & 0.634 \\
\hline $\mathrm{HCO}_{3} 28$ & Z & 33 & 2.09 & 45 & 0.28 & AX-80973925 & 33940034 & 0.0543 & 0.608 \\
\hline $\mathrm{HCO}_{3} 28$ & Z & 35 & 1.67 & 128 & 0.50 & AX-80901519 & 35319963 & 0.0589 & 0.379 \\
\hline $\mathrm{HCO}_{3} 28$ & Z & 7 & 1.47 & 2 & 0.9 & AX-77264084 & 7705768 & 0.0806 & 0.311 \\
\hline $\mathrm{HCO}_{3} 28$ & Z & 70 & 1.45 & 55 & 0.28 & AX-77257752 & 70210948 & 0.0625 & 0.376 \\
\hline $\mathrm{HCO}_{3} 28$ & Z & 69 & 1.31 & 113 & 0.40 & AX-80879264 & 69810199 & 0.0525 & 0.370 \\
\hline $\mathrm{HCO}_{3} 28$ & 6 & 25 & 0.75 & 325 & 0.86 & AX-76932184 & 25826439 & 0.0083 & 0.466 \\
\hline $\mathrm{HCO}_{3} 28$ & Z & 71 & 0.74 & 183 & 0.62 & AX-80943753 & 71554374 & 0.0520 & 0.360 \\
\hline $\mathrm{HCO}_{3} 28$ & 6 & 26 & 0.53 & 291 & 0.83 & AX-76933234 & 26203623 & 0.0092 & 0.493 \\
\hline $\mathrm{TCO}_{2} 28$ & Z & 69 & 3.63 & 113 & 0.46 & AX-80879264 & 69810199 & 0.1357 & 0.370 \\
\hline $\mathrm{TCO}_{2} 28$ & Z & 30 & 3.04 & 74 & 0.44 & AX-77209983 & 30284984 & 0.1424 & 0.671 \\
\hline $\mathrm{TCO}_{2} 28$ & Z & 8 & 2.30 & 24 & 0.25 & AX-80958477 & 8485438 & 0.0859 & 0.357 \\
\hline $\mathrm{TCO}_{2} 28$ & Z & 33 & 1.73 & 45 & 0.28 & AX-80973925 & 33940034 & 0.0667 & 0.608 \\
\hline $\mathrm{TCO}_{2} 28$ & Z & 5 & 1.60 & 62 & 0.29 & AX-80834191 & 5042699 & 0.0700 & 0.634 \\
\hline $\mathrm{TCO}_{2} 28$ & Z & 7 & 1.23 & 2 & 0.7 & AX-77264084 & 7705768 & 0.0707 & 0.311 \\
\hline $\mathrm{TCO}_{2} 28$ & Z & 70 & 0.91 & 55 & 0.26 & AX-77257752 & 70210948 & 0.0434 & 0.376 \\
\hline $\mathrm{TCO}_{2} 28$ & Z & 35 & 0.80 & 128 & 0.48 & AX-80901519 & 35319963 & 0.0419 & 0.379 \\
\hline
\end{tabular}


Table 2 Windows explaining a significant percentage $(\geq 0.5)$ of genetic variance (Continued)

\begin{tabular}{|c|c|c|c|c|c|c|c|c|c|}
\hline $\mathrm{TCO}_{2} 28$ & 6 & 25 & 0.66 & 325 & 0.85 & AX-76932184 & 25826439 & 0.0080 & 0.466 \\
\hline $\mathrm{TCO}_{2} 28$ & 26 & 3 & 0.51 & 616 & 0.98 & AX-80958155 & 3785485 & 0.0079 & 0.513 \\
\hline $\mathrm{TCO}_{2} 28-20$ & 10 & 5 & 0.51 & 515 & 0.93 & AX-75615576 & 5758221 & 0.0067 & 0.355 \\
\hline K20 & 10 & 16 & 0.76 & 372 & 0.92 & AX-75589587 & 16018566 & 0.0041 & 0.249 \\
\hline $\mathrm{K} 20$ & 10 & 18 & 0.53 & 496 & 0.96 & AX-75597981 & 18294286 & 0.0038 & 0.278 \\
\hline K20 & 12 & 17 & 0.53 & 242 & 0.72 & AX-75701199 & 17759131 & 0.0043 & 0.646 \\
\hline K20 & 26 & 3 & 0.50 & 616 & 0.96 & AX-76340450 & 3273628 & 0.0036 & 0.180 \\
\hline $\mathrm{K} 28-20$ & 12 & 16 & 1.29 & 246 & 0.75 & AX-75696568 & 16220734 & 0.0036 & 0.650 \\
\hline $\mathrm{K} 28-20$ & 12 & 17 & 0.69 & 242 & 0.70 & AX-75701149 & 17743731 & 0.0043 & 0.633 \\
\hline iCa28 & 26 & 3 & 0.52 & 616 & 0.96 & AX-76343628 & 3922118 & 0.0076 & 0.550 \\
\hline Hct28 & 14 & 11 & 1.78 & 391 & 0.94 & AX-75776707 & 11791127 & 0.0096 & 0.502 \\
\hline Hct28 & 1 & 169 & 1.17 & 196 & 0.83 & AX-75336362 & 169571235 & 0.0110 & 0.714 \\
\hline Hct28 & 28 & 3 & 1.01 & 437 & 0.92 & AX-76384000 & 3944019 & 0.0116 & 0.397 \\
\hline Hct28 & 28 & 4 & 0.93 & 328 & 0.91 & AX-76385356 & 4197143 & 0.0113 & 0.408 \\
\hline Hct28 & 22 & 3 & 0.88 & 573 & 0.95 & AX-76269662 & 3474970 & 0.0072 & 0.513 \\
\hline Hct28 & 10 & 16 & 0.59 & 372 & 0.90 & AX-75589730 & 16057907 & 0.0070 & 0.254 \\
\hline $\mathrm{Hb} 28$ & 14 & 11 & 1.64 & 391 & 0.95 & AX-75776707 & 11791127 & 0.0091 & 0.502 \\
\hline $\mathrm{Hb} 28$ & 1 & 169 & 1.33 & 196 & 0.83 & AX-75337336 & 169979876 & 0.0121 & 0.322 \\
\hline $\mathrm{Hb} 28$ & 28 & 3 & 0.96 & 437 & 0.91 & AX-76384000 & 3944019 & 0.0112 & 0.397 \\
\hline $\mathrm{Hb} 28$ & 28 & 4 & 0.94 & 328 & 0.92 & AX-76385356 & 4197143 & 0.0103 & 0.408 \\
\hline $\mathrm{Hb} 28$ & 22 & 3 & 0.79 & 573 & 0.95 & AX-76269662 & 3474970 & 0.0073 & 0.513 \\
\hline $\mathrm{Hb} 28$ & 10 & 16 & 0.60 & 372 & 0.90 & AX-75590148 & 16177101 & 0.0077 & 0.295 \\
\hline $\mathrm{Hb} 28$ & 1 & 170 & 0.50 & 176 & 0.65 & AX-75337520 & 170074107 & 0.0083 & 0.676 \\
\hline $\mathrm{Hb} 28-20$ & 22 & 3 & 1.71 & 573 & 0.96 & AX-76272400 & 3857927 & 0.0072 & 0.533 \\
\hline $\mathrm{sO}_{2} 28$ & 25 & 0 & 1.23 & 364 & 0.91 & AX-75758019 & 5130673 & 0.0070 & 0.531 \\
\hline $\mathrm{sO}_{2} 28$ & 24 & 3 & 0.55 & 581 & 0.94 & AX-76328225 & 36480 & 0.0111 & 0.618 \\
\hline $\mathrm{sO}_{2} 28-20$ & 17 & 6 & 0.53 & 324 & 0.83 & AX-75872796 & 6506736 & 0.0066 & 0.412 \\
\hline $\mathrm{sO}_{2} 28-20$ & 17 & 7 & 0.53 & 467 & 0.88 & AX-75875111 & 7125729 & 0.0066 & 0.172 \\
\hline Glu20 & 10 & 4 & 0.67 & 548 & 0.95 & AX-80975590 & 4452892 & 0.0067 & 0.740 \\
\hline Glu28 & 22 & 3 & 1.09 & 573 & 0.94 & AX-76273189 & 3966852 & 0.0070 & 0.585 \\
\hline Glu28 & Z & 5 & 0.79 & 62 & 0.28 & AX-80834191 & 5042699 & 0.0246 & 0.634 \\
\hline Glu28 & Z & 70 & 0.74 & 55 & 0.24 & AX-77257752 & 70210948 & 0.0266 & 0.376 \\
\hline Glu28 & Z & 69 & 0.64 & 113 & 0.42 & AX-80879264 & 69810199 & 0.0187 & 0.371 \\
\hline
\end{tabular}

${ }^{a}$ Blood chemistry components were measured pre-heat (day 20), on the seventh day of heat treatment (day 28), and the calculated differential due to heat (day 28-20)

${ }^{\mathrm{b}}$ Frequency in which the window was included in the MCMC iterations (post-burn-in)

'SNP within the specified window which was most frequently included in the MCMC iterations (post-burn-in), and is therefore predicted to have the greatest

effect on the phenotype

dPosition of SNPs in base pairs on Gallus-gallus (version 4.0) chromosome

eFrequency in which the SNP was included in the MCMC iterations (post-burn-in) model

${ }^{f}$ Allele frequency of the SNP in the genotyped population $(N=458)$

respiratory alkalosis, metabolic alkalosis, blood volume and oxygen carrying capacity, electrolytes, and glucose) for discussion.

\section{Population studied}

Previous generations of this AIL were used for several QTL mapping studies and allowed the identification of many QTL including 257 for growth and body composition [20-24], 93 for skeletal integrity [25], 51 for metabolic traits [18], 12 for response to Salmonella enteritidis challenge [26-28], and 35 for response to heat stress [29]. Therefore, collectively, a wide range of traits have been associated with a large number of QTL in this AIL. The continued erosion of 
Table 3 Top 20 canonical pathways for QTL identified for all traits, and for co-localized QTL

\begin{tabular}{|c|c|c|c|}
\hline \multicolumn{4}{|l|}{ Pathways for all identified QTL } \\
\hline Pathway & $P$-value & Ratio: & Genes in pathway that were identified in current study \\
\hline $\begin{array}{l}\text { 1D-myo-inositol Hexakisphosphate Biosynthesis II } \\
\text { (Mammalian) }\end{array}$ & 1.93E-03 & $4 / 19$ & INPP5E,IPMK,SEC16A,PMPCA \\
\hline AMPK Signaling & $2.15 \mathrm{E}-03$ & $13 / 178$ & $\begin{array}{l}\text { CHRNA5,MTOR,STRADA,AK8,INSR,CHRNA3,PPM1J,CHRNB4,PIK3R2, } \\
\text { ADRA2A,TSC1,FOXO1,ADRA1A }\end{array}$ \\
\hline Angiopoietin Signaling & $1.22 \mathrm{E}-03$ & $6 / 66$ & NRAS,PIK3R2,BIRC5,CASP9,IKBKAP,FOXO1 \\
\hline Calcium Signaling & $1.51 \mathrm{E}-02$ & $11 / 178$ & $\begin{array}{l}\text { CALR,CHRNA5,MYL4,CHRNB4,CAMK4,CHRNA3,CAMK1G,MEF2D, } \\
\text { TPM1,RAP1A,MEF2A }\end{array}$ \\
\hline Cardiac Hypertrophy Signaling & $5.80 \mathrm{E}-03$ & $14 / 223$ & $\begin{array}{l}\text { MTOR,MYL4,CAMK4,RHOC,IGF1R,NRAS,PIK3R2,RHOT1,ADRA2A, } \\
\text { MEF2D,MAP3K3,CACNA1D,MEF2A,ADRA1A }\end{array}$ \\
\hline D-myo-inositol $(1,3,4)$-trisphosphate Biosynthesis & 1.93E-03 & $4 / 19$ & INPP5E,IPMK,SEC16A,PMPCA \\
\hline D-myo-inositol $(1,4,5)$-trisphosphate Degradation & $1.44 \mathrm{E}-02$ & $3 / 18$ & INPP5E,SEC16A,PMPCA \\
\hline Dopamine Degradation & $8.29 \mathrm{E}-03$ & $4 / 28$ & ALDH1A1,ALDH1A3,MAOB,ALDH4A1 \\
\hline ERK5 Signaling & $2.28 \mathrm{E}-03$ & $7 / 63$ & MAP2K5,NRAS,NTRK1,MEF2D,NGF,MAP3K3,MEF2A \\
\hline Ethanol Degradation IV & $4.02 \mathrm{E}-03$ & $4 / 23$ & ALDH1A1,TYRP1,ALDH1A3,ALDH4A1 \\
\hline Glioblastoma Multiforme Signaling & $1.03 \mathrm{E}-02$ & $10 / 146$ & WNT2B,IGF1R,NRAS,MTOR,PIK3R2,WNT5A,RHOC,RHOT1,TSC1, FOXO1 \\
\hline Glioma Signaling & $7.71 \mathrm{E}-03$ & $8 / 98$ & ABL1,TGFA,IGF1R,NRAS,MTOR,PIK3R2,CAMK4,CAMK1G \\
\hline Histamine Degradation & $1.22 \mathrm{E}-02$ & $3 / 17$ & ALDH1A1,ALDH1A3,ALDH4A1 \\
\hline Human Embryonic Stem Cell Pluripotency & $1.85 \mathrm{E}-03$ & $11 / 134$ & $\begin{array}{l}\text { WNT2B,PIK3R2,WNT5A,SMAD3,SMAD6,NTRK1,TCF7L2,BMP2,NGF, } \\
\text { FOXO1,NOG }\end{array}$ \\
\hline Non-Small Cell Lung Cancer Signaling & $1.13 \mathrm{E}-02$ & $6 / 65$ & ABL1,TGFA,NRAS,PIK3R2,CASP9,RXRA \\
\hline Nur77 Signaling in T Lymphocytes & $1.26 \mathrm{E}-03$ & $7 / 57$ & MAP2K5,SIN3B,CASP9,RXRA,CAMK4,MEF2D,MAP3K3 \\
\hline Putrescine Degradation III & $2.84 \mathrm{E}-03$ & $4 / 21$ & $\mathrm{ALDH} 1 \mathrm{~A} 1, \mathrm{ALDH} 1 \mathrm{~A} 3, \mathrm{MAOB}, \mathrm{ALDH} 4 \mathrm{~A} 1$ \\
\hline $\begin{array}{l}\text { Superpathway of D-myo-inositol (1,4,5)-trisphosphate } \\
\text { Metabolism }\end{array}$ & 4.71E-03 & $4 / 24$ & INPP5E,IPMK,SEC16A,PMPCA \\
\hline Thyroid Cancer Signaling & $9.69 \mathrm{E}-04$ & $6 / 40$ & NRAS,RET,RXRA,NTRK1,TCF7L2,NGF \\
\hline Tryptophan Degradation X (Mammalian, via Tryptamine) & $4.02 \mathrm{E}-03$ & $4 / 23$ & $\mathrm{ALDH} 1 \mathrm{~A} 1, \mathrm{ALDH} 1 \mathrm{~A} 3, \mathrm{MAOB}, \mathrm{ALDH} 4 \mathrm{~A} 1$ \\
\hline \multicolumn{4}{|l|}{ Pathways identified for co-localized QTL } \\
\hline Pathway & $P$-value & Ratio: & Genes in pathway that were identified in current study \\
\hline 2-oxobutanoate Degradation I & $4.22 \mathrm{E}-02$ & $1 / 5$ & MCEE \\
\hline AMPK Signaling & $4.42 \mathrm{E}-03$ & $6 / 178$ & CHRNA5,PPM1J,CHRNB4,INSR,CHRNA3,ADRA1A \\
\hline Calcium Signaling & $1.55 \mathrm{E}-04$ & $8 / 178$ & CALR,CHRNA5,CHRNB4,CHRNA3,CAMK1G,TPM1,RAP1A,MEF2A \\
\hline Cardiac Hypertrophy Signaling & 4.35E-02 & $5 / 223$ & IGF1R,NRAS,RHOC,MEF2A,ADRA1A \\
\hline CDK5 Signaling & 4.94E-02 & $3 / 105$ & NRAS,PPM1J,NGF \\
\hline Cholecystokinin/Gastrin-mediated Signaling & 4.95E-02 & $3 / 245$ & NRAS,RHOC,MEF2A \\
\hline CTLA4 Signaling in Cytotoxic T Lymphocytes & 4.01E-02 & $3 / 88$ & PPM1J,PTPN22,AP1M1 \\
\hline ERK5 Signaling & $1.69 \mathrm{E}-02$ & $3 / 63$ & NRAS,NGF,MEF2A \\
\hline Germ Cell-Sertoli Cell Junction Signaling & 4.93E-02 & $4 / 160$ & NRAS,TJP1,RHOC,RAB8B \\
\hline Glioblastoma Multiforme Signaling & $3.73 \mathrm{E}-02$ & $4 / 146$ & WNT2B,IGF1R,NRAS,RHOC \\
\hline Glioma Signaling & $1.01 \mathrm{E}-02$ & $4 / 98$ & TGFA,IGF1R,NRAS,CAMK1G \\
\hline Integrin Signaling & 3.33E-02 & $5 / 207$ & NRAS,TSPAN2,RHOC,TLN2,RAP1A \\
\hline Methylmalonyl Pathway & 3.39E-02 & $1 / 4$ & MCEE \\
\hline mTOR Signaling & $2.28 \mathrm{E}-02$ & $5 / 187$ & NRAS,PPM1J,INSR,RHOC,RPS15 \\
\hline NF-kB Signaling & 1.65E-02 & $5 / 172$ & TGFA,IGF1R,NRAS,INSR,NGF \\
\hline PTEN Signaling & $1.89 \mathrm{E}-02$ & $4 / 118$ & IGF1R,NRAS,INSR,MAGI3 \\
\hline Renal Cell Carcinoma Signaling & $2.32 \mathrm{E}-02$ & $3 / 71$ & TGFA,NRAS,RAP1A \\
\hline
\end{tabular}


Table 3 Top 20 canonical pathways for QTL identified for all traits, and for co-localized QTL (Continued)

\begin{tabular}{|c|c|c|c|}
\hline STAT3 Pathway & $2.49 \mathrm{E}-02$ & $3 / 73$ & IGF1R,NRAS,INSR \\
\hline TCA Cycle II (Eukaryotic) & $1.65 \mathrm{E}-02$ & $2 / 23$ & IDH3A,ACO1 \\
\hline Thyroid Cancer Signaling & 4.62E-02 & $2 / 40$ & NRAS,NGF \\
\hline
\end{tabular}

Linkage Disequilibrium (LD) in this population over subsequent generations, combined with the availability of larger SNP panels, creates a unique opportunity to more finely map the location of QTL that are in LD with a causal mutation.

\section{Respiratory alkalosis \\ Phenotypic measurements}

During periods of intense heat, chickens increase the depth and frequency of respiration to decrease core body temperature [30]. Broilers that are heat stressed increase panting and display signs of respiratory alkalosis [10], which is caused by an increase in the amount of $\mathrm{CO}_{2}$ expelled from the lungs, and a consequent increase in $\mathrm{pH}$ within the blood, and an increase in $\mathrm{pO}_{2}$ within the blood. We investigated blood $\mathrm{pH}, \mathrm{pCO}_{2}$, and $\mathrm{pO}_{2}$ to characterize respiratory alkalosis induced by heat stress.

Occurrence of respiratory alkalosis was clearly demonstrated in the current study by a significant increase in blood $\mathrm{pH}$ and significant decrease in $\mathrm{pCO}_{2}$ due to heat treatment, in agreement with previous studies. Heat stress for two hours at $32{ }^{\circ} \mathrm{C}$ in broilers at 35 days of age significantly increases blood $\mathrm{pH}$ and decreases $\mathrm{pCO}_{2}$ [31] and, in another study using broilers, heat stressed at $32{ }^{\circ} \mathrm{C}$ for 2 weeks at 28 days of age in birds that were panting [10]. We found $\mathrm{pO}_{2}$ increased in response to heat treatment, although not significantly. In a study using 35 day old broilers, blood $\mathrm{pO}_{2}$ significantly increased after cyclical heat stress for 10 days at $35^{\circ} \mathrm{C}$ [32].

\section{Heritabilities}

Only one other published study has estimated heritabilities of blood components in chickens under thermal stress [33]. The current study, therefore, adds substantially to the body of information on response of birds to thermal stress by estimating heritabilities of blood component levels and changes under heat stress and thermoneutral conditions. In broiler chickens at 22 days of age reared under cold stress conditions, heritabilities for blood $\mathrm{pH}, \mathrm{pCO}_{2}$, and $\mathrm{pO}_{2}$ were estimated at $0.15,0.15$, and 0.03 , respectively [33], in agreement with the current study's estimates for thermoneutral and heat conditions. Our estimates for the changes in these blood components due to heat treatment was much lower, suggesting that the ability to select for the response to heat stress may be difficult.

\section{GWAS}

To our knowledge, QTL for blood $\mathrm{pH}, \mathrm{pCO}_{2}$, and $\mathrm{pO}_{2}$ in chickens have not been previously reported. Identification of QTL for blood pH on different chromosomes across measurement phases, indicates that genetic control of these traits exists and is partly dependent on the environment. Co-localized QTL for $\mathrm{pCO}_{2} 20$ and $\mathrm{pCO}_{2} 28-20$ on GGA28, and for $\mathrm{pCO}_{2} 28$ and $\mathrm{pCO}_{2} 28-20$ on GGA10, suggest that the same genetic regions contribute to control of $\mathrm{pCO}_{2}$ level independent of environmental temperature. The presence of co-localized QTL between measurement phases was not expected, based on the lack of phenotypic correlations $(r=0.00)$.

\section{Metabolic alkalosis \\ Phenotypic measurements}

Metabolic alkalosis occurs when there is a disturbance in the fixed acids and bases in the extracellular fluid [11]. Imbalance of dietary $\mathrm{Na}, \mathrm{K}$, or $\mathrm{Ca}$ can result in metabolic alkalosis [34], which is characterized by an increase in blood $\mathrm{pH}, \mathrm{HCO}_{3}$, and base excess, and can be induced in growing layers by high levels of calcium in feed [35].

Base excess is considered a comprehensive measure of the metabolic components of bases, which reflects the nonrespiratory contribution to changes in acid-base disturbances [36]. Base excess can be altered by changing the cation:anion ratio in the diet of broiler chickens and is associated with body weight and bone density [37]. In the current study, base excess significantly increased after heat treatment, which is consistent with the hypothesis that chickens experience metabolic alkalosis under heat stress.

$\mathrm{HCO}_{3}$ is the most abundant buffer in the blood, is primarily regulated by the kidneys, and is a metabolic component of acid-base balance [36]. We observed a significant increase in $\mathrm{HCO}_{3}$ due to heat treatment. These results contrasted with a previous study using broilers at 28 days of age in which blood $\mathrm{HCO}_{3}$ 
significantly decreased in panting birds under acute heat stress [10], and another study using male broilers that reported a decrease in $\mathrm{HCO}_{3}$ after a heat stress at $32{ }^{\circ} \mathrm{C}$ for $10 \mathrm{~h} \mathrm{[13]}$. $\mathrm{TCO}_{2}$ also increased in response to heat treatment. It was unexpected to observe a decrease in base excess, consistent with metabolic alkalosis, while $\mathrm{HCO}_{3}$ and $\mathrm{TCO}_{2}$ increased, because the traits are highly positively correlated within all treatment phases $(r \geq$ 0.95).

\section{Heritabilities}

We estimated heritability of base excess between 0.000.10 , of $\mathrm{HCO}_{3}$ between $0.03-0.23$, and of $\mathrm{TCO}_{2}$ between 0.01-0.13. In broiler chickens at 22 days of age reared under cold stress conditions, blood $\mathrm{HCO}_{3}$ and $\mathrm{TCO}_{2}$ heritability were both estimated at 0.19 [33].

\section{GWAS}

We are the first to report QTL in chickens for blood base excess, $\mathrm{HCO}_{3}$, and $\mathrm{TCO}_{2}$, which are related to metabolic alkalosis. QTL for base excess are located on separate chromosomes for all measurement phases, indicating a strong genetics by environmental $(G \times E)$ temperature interaction. The phenotypic correlations for base excess between measurement phases were both very low $(r=0.03)$. The QTL for base excess on GGA18 overlap with $\mathrm{pH}$ measured at thermoneutrality and were highly correlated $(r=0.78)$. Surprisingly, QTL for $\mathrm{HCO}_{3}$ were only identified during heat treatment and were on GGA6 and GGAZ. Ten of the eleven QTL for $\mathrm{TCO}_{2}$ measured during heat co-localized with QTL for $\mathrm{HCO}_{3}$ and these co-localized regions were located on GGA6, 26 , and $\mathrm{Z}$.

\section{Electrolytes \\ Phenotypic measurements}

Blood $\mathrm{K}$ and $\mathrm{Na}$ levels numerically increased and $\mathrm{iCa}$ statistically increased in response to heat treatment. This is in disagreement with previous reports of decreasing levels of both $\mathrm{K}$ and $\mathrm{Na}$ in response to heat stress, likely due to increased water intake which results in decreased concentrations of electrolytes within the blood $[6,13,38]$.

\section{Heritabilities}

Heritability of $\mathrm{K}$ and $\mathrm{Na}$ blood levels in humans has been estimated to be very low, 0.03 and 0.04 , respectively [39], in agreement with our low heritability estimates during heat and for the calculated differential. In contrast, our estimates for heritability under thermoneutral conditions for $\mathrm{K}$ and $\mathrm{Na}$ were higher, 0.20 and 0.08 , respectively. Estimated heritability was 0.02 for ionized Ca measured during heat stress, lower than the 0.19 of mice in thermoneutral conditions [40]. The estimated heritability was low, for both thermoneutral (0.04) and the differential due to heat $(0.01)$, indicating the genetic component for ionized $\mathrm{Ca}$ is dependent upon environmental conditions at the time of measurement. The low heritabilities of these traits during heat and for the calculated differential due to heat treatment suggest it may be difficult to select for these traits.

\section{GWAS}

This research is the first to describe QTL for the electrolyte-balance traits of blood $\mathrm{K}, \mathrm{Na}$, and ionized $\mathrm{Ca}$ in the chicken. In swine, QTL have been identified for these traits [41]. QTL for blood $\mathrm{K}$ were located on GGA10, 12, and 26. QTL were identified for $\mathrm{K}$ across the thermoneutral and differential due to heat measurement phases, indicating genetic control of this component in this region on GGA12 despite environmental temperature. The correlation between thermoneutral and the differential was moderate $(r=0.10)$. No significant QTL for Na were identified in the current study and a single QTL for ionized Ca was located on GGA26 for the measurement taken during heat.

\section{Blood volume and oxygen saturation Phenotypic measurements}

Changes in blood volume and oxygen carrying capacity occur in chickens during periods of heat stress [5]. Both hematocrit and hemoglobin significantly increased due to heat treatment, which may be the result of dehydration. This result contrasts with a previous study using male broilers in which both decreased after an acute heat stress at $32{ }^{\circ} \mathrm{C}$ for $10 \mathrm{~h}$ [6]. Blood $\mathrm{sO}_{2}$ is a measure of oxyhemoglobin in relation to total hemoglobin that is able to bind oxygen [36], and this significantly increased during heat treatment.

\section{Heritability}

The heritability of Hct was estimated as very low at 0.01 and 0.02 for pre-heat and the differential, respectively, while during heat was moderately heritable at 0.21 . Heritability has been estimated for hematocrit at 0.39 in domestic fowl [42]. The increase in heritability when measured during heat stress indicates that this trait may be useful for selection. Heritability estimates of $\mathrm{sO}_{2}$ were very low (0.01-0.03), which is in general agreement with a previously reported value of 0.07 in cold-stressed broiler chickens at 22 days of age [33].

\section{GWAS}

Seven QTL for haematocrit have been identified in chickens (www.animalgenome.org). In a broiler by layer F2 intercross, QTL for hematocrit were located on GGA1, 2, 6, and 14 [43]; in a Fayoumi by Leghorn F2 intercross on GGA1 and GGA15 [44], and in a broiler 
by layer cross on GGA1 [45]. Our current work confirmed previously identified QTL for Hct28 on GGA1 and GGA14. Novel QTL for Hct were on GGA10, 22, and 28. Most of the QTL identified in the current study for $\mathrm{Hb}$ co-localized with those identified for Hct, with the addition of a relatively large QTL for $\mathrm{Hb} 28-20$ on GGA22, explaining $1.7 \%$ of the genetic variation. The co-localization of QTL among Hct and $\mathrm{Hb}$ is expected because they have very high positive phenotypic correlations across all measurement phases $(r \geq 0.99)$. We identified novel QTL for $\mathrm{sO}_{2}$ on GGA17, 24, and 25, none of which overlapped between measurement phases, indicating separate genetic control of this trait dependent upon environmental temperature. A previous study using a commercial broiler line identified one on GGA16 [46]. Thus, QTL for $\mathrm{sO}_{2}$ appear to be population specific.

\section{Glucose}

\section{Phenotypic measurement}

Glucose is the body's primary source of energy, and blood Glu significantly decreased due to heat treatment in the current study. In contrast, male broilers had a significant

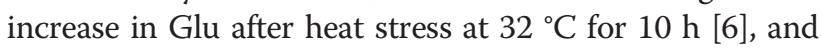
in broiler chicks of 5 weeks of age at $35-40{ }^{\circ} \mathrm{C}$ [47]. In chicken lines divergently selected for blood glucose concentration, the low glucose line was less efficient at food utilization compared to the high glucose line [48], which may indicate that the decrease in glucose we see during heat stress may contribute to inefficiency in food utilization.

\section{Heritability}

The current study estimated heritabilities for glucose ranging between 0.02-0.19. In a study using chickens divergently selected for blood glucose concentration, heritability was estimated at 0.25 [48].

\section{GWAS}

We identified QTL for Glu20 and Glu28 on GGA10, 22, and Z, while QTL were mapped to GGA2, 7, and Z in the $F 2$ generation of the same chicken population under thermoneutral conditions [18]. The two studies may have detected the same QTL on chromosome Z and, due to the breakdown of LD over the generations, the current study may have mapped the QTL more accurately. In an F2 intercross between fat and lean broilers, QTL were identified for blood glucose on GGA3 and GGA18 [49], and for fasting plasma glucose on GGA5, 6,13 , and 26 [15]. A study using an F2 of broilers divergently selected for growth, identified QTL for plasma glucose on GGA20 and GGA27 [16]. Thus, QTL location for blood glucose level appears to be heat and/or population specific.

\section{Pathway analysis}

Considering all measured traits, we identified a total of 32 unique QTL. All annotated genes within the QTL regions were used for pathway analysis using IPA and many significantly associated canonical pathways were identified including AMPK signalling and Angiopoietin signalling were identified. The top 20 pathways are found in Table 3. AMPK is a master metabolic regulator involved in metabolism [50] and, thus, may be a pathway which warrants further investigation for involvement in production traits during heat stress. During high ambient temperatures chickens redirect blood flow to the body surface to decrease body temperature [5], and the angiopoietin signalling pathway functions in blood vessel development which may help alleviate temperature stress.

The co-localized regions resulted in many significant canonical pathways and the top 20 pathways are found Table 3. Of particular interest is the Cardiac Hypertrophy signalling pathway $(P=4.35 \mathrm{E}-02)$. QTL for hemoglobin and hematocrit represent 3 (7 total) regions of co-localization and there is a positive linear relationship between hematocrit and heart weight in chickens under heat stress [5]; therefore, this pathway likely contributes to the response to heat stress in chickens.

\section{Candidate genes for co-localized QTL}

The QTL regions that co-localized for three or more traits were further investigated for positional, functional candidate genes to give further insight into the biological mechanisms involved in the response of blood components to heat stress. The identified genes are located in Additional file 1: Table S1.

There are 51 genes in the region on GGA10 between 3-6 $\mathrm{Mb}$ that contained QTL for Glu20, $\mathrm{pCO}_{2} 28$, and $\mathrm{TCO}_{2} 28-20$. With 2 of these 3 traits associated with $\mathrm{CO}_{2}$ concentration, CA12 (carbonic anhydrase) is a likely candidate gene involved in the $\mathrm{CO}_{2}$ response to heat stress. Carbonic anhydrases catalyse the reaction of $\mathrm{CO}_{2}$ and $\mathrm{H}_{2} \mathrm{O}$ to form $\mathrm{HCO}_{3}$ and $\mathrm{H}+$, and thus may stabilize blood acid base balance during heat stress. Another strong functional candidate in this region is $H S P 40$, a member of the heat shock protein family that functions as a molecular chaperone to prevent cellular damage during heat stress [51]. A candidate gene in this region for glucose level is GCNT3, a glucosamine acetyl transferase which is associated with glucose metabolism in humans [52].

Fourteen genes were identified on GGA10 between 16-17 Mb, where QTLs co-localized for $\mathrm{pH} 28-20$, Hct28, Hb28, and K20. Many QTL in chicken have been identified in this region including those related to growth [22, 53-55], abdominal fat [23, 49, 56], and 
the stress-associated trait of fear response [57]. A strong candidate gene is ALDH6 (aldehyde dehydrogenase) which functions to convert aldehydes to carboxylic acids. This gene may function to maintain blood acid base balance during heat stress. Another gene in this region is IGF1 (insulin like growth factor 1), which has many roles and is a biomarker for growth [58].

Four genes were identified on GGA22 between 3-4 Mbs, where QTL were co-localized for Hct28, Hb28, Hb28-20, and Glu28. To our knowledge, no QTL have been reported in this region. Because all traits were measured during heat treatment or as the differential, we propose these to be heat specific QTL. Candidate genes TGFA (pretransforming growth factor) and ADRA1A (adrenergic receptor) both regulate cell growth. It is known that metabolic changes occur during periods of heat in chickens that contribute to reduction in growth, independent upon feed intake [9].

There are 48 genes in the $1 \mathrm{Mb}$ region on GGA26 between 3-4 Mbs, where QTL co-localized for $\mathrm{TCO}_{2} 28$, K20, and iCa28. Notably, a QTL for tibia bone mineral density identified in a commercial broiler and layer cross is located within this region [59]. This co-localization suggests that this locus might be involved in both blood calcium and bone density, and therefore, may be an ideal candidate for further investigation to understand the physiological response to heat stress on bone mineral density.

There are 86 genes in the $2 \mathrm{Mb}$ region on GGA28 between 3-5 Mb where QTLs co-localize for $\mathrm{pH} 20$, $\mathrm{Hb} 28$, Hct28, $\mathrm{pCO}_{2} 20$, and $\mathrm{pCO}_{2} 28-20$. A QTL for heart weight, relating to susceptibility of pulmonary hypertension [60] co-localizes with those identified here. Many of these genes are related to membrane transport of solutes and DNA transcription. The solute carriers SLC39A3, SLC25A42 and SLC35E1 were identified, as well as CHERP and CIB3, involved in calcium homeostasis. Transcription-related genes include SUGP1, which is involved in RNA splicing; RFXANK, a DNA-binding protein; NR2C2AP, a nuclear receptor protein; $D D X 49$, an RNA helicase; $E L L$, an RNA polymerase II elongation factor; and $\operatorname{SIN} 3 B$ a transcriptional regulator.

On GGAZ, 2 genes were identified between 5-7 Mbs, where QTL co-localize for Glu28, $\mathrm{HCO}_{3} 28$, and $\mathrm{TCO}_{2} 28$. The only reported QTL near this region is for antibody response to KLH antigen [61]. Heat stress is known to reduce antibody titre in chickens [62], and this locus may be involved in the complex interaction of heat and antibody titre. Although, antibody levels were not measured in the current study. During periods of heat stress, DNA transcription, RNA translation, and cellular proliferation are altered [63] and we observed several genes in this region related to these particular responses including: KIAA1328, involved in chromosomal integrity during mitosis; and TPGS2, involved in tubulin formation.

On GGAZ, 21 genes were identified between 69-71 Mbs, where QTL co-localize for Glu28, $\mathrm{HCO}_{3} 28$, and $\mathrm{TCO}_{2} 28$. The one QTL that is near this region was identified in a previous generation of the same AIL as the current study, and is for bone mineral density [25]. A recent study found that heat stress in broilers results in decreased bone mineral density [64]. In humans, low serum bicarbonate levels are associated with decreased bone mineral density [65]. Although this relationship has yet to be elucidated in the chicken, further studies should investigate the association between blood chemistry variables and bone mineral density. The genes identified in the current study that are primarily involved in DNA transcription include $X P A$, which is a DNA repair protein, FOXE3 which is part of the forkhead box, and SNORA66 which is small nuclear RNA. Additionally, microRNAs gga-mir-2954, gga-mir-2131, and gga-mir1583 were identified in this region. An additional gene of interest identified was DNAJA1, which is part of the heat shock family of proteins.

\section{QTL for blood components reveal orthologous genes between chicken and swine}

QTL for blood $\mathrm{pCO}_{2}$ in the current study were located on GGA1, 3, 9, 10, 23, 27, and 28. In swine, QTL for blood $\mathrm{pCO}_{2}$ are on chromosomes 6, 7, 8, 9, and $\mathrm{X}$ [41]. We identified a region of synteny between chicken GGA1, 110-111 Mb, and pig chromosome $\mathrm{X}, 43-44 \mathrm{Mb}$ (Fig. 3a), which contains a $\mathrm{pCO}_{2}$ QTL and several orthologous genes including FUNDC1, EFHC2, NDP, and MAOA. Another region of synteny exists between chicken chromosome 10, 1-4 Mb, and pig chromosome 7, 53-65 Mb (Fig. 3b/c), which contains several orthologous genes including, but not limited to, UBE2Q2, DNAJ, GRAMD2, ADPGK, NEO1, CLK3, SCAMP5, CSK, and MPI. This region contains the carboxylic anhydrase gene (CA12) in chicken, which is involved in calcium metabolism, but this gene maps on pig chromosome 1, a chromosome on which no QTL have been reported for blood chemistry measurements. The region on GGA10, $1-4 \mathrm{Mb}$, contains QTL for Glu20, $\mathrm{pCO}_{2} 28, \mathrm{pCO}_{2} 28-20$, and $\mathrm{TCO}_{2} 28-20$. The syntenic region in swine contains co-localized QTL for $\mathrm{pCO}_{2}, \mathrm{HCO}_{3}, \mathrm{TCO}_{2}$, and base excess [41].

A QTL for blood K level mapped to syntenic regions in chicken GGA10, 16-17 Mb, in our line and swine chromosome 1, 63-226 Mb (Fig. 3d) in a previous study [66]. An orthologous gene of interest in this region is IGF-1. 

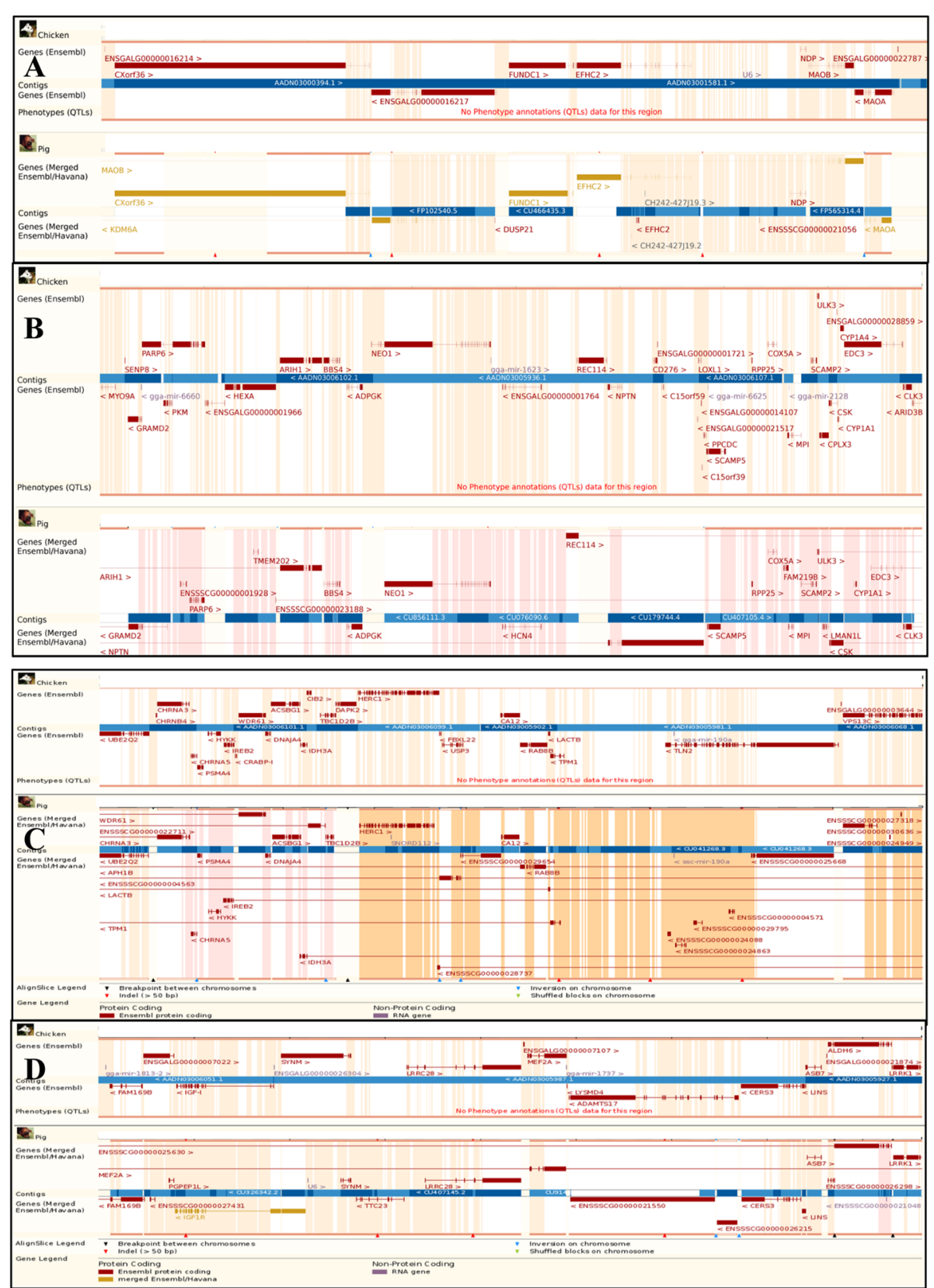

Fig. 3 Syntenic regions between chicken and swine. Syntenic regions between chicken and pig containing QTL for blood component traits. a QTL for $\mathrm{pCO}_{2}$ in both chicken and pig. Chicken QTL on GGA1 at 110-111 Mb in chicken syntenic with pig on chromosome X, 43-44 Mb. b/c GGA10 1-2 Mb in chicken and pig chromosome 7 53-60 Mb d. GGA10 16-17 Mb and swine chromosome 1, 63-226 Mb

\section{Conclusions}

The results of this study contribute to the currently sparse knowledge of levels and heritabilities of several blood components under thermoneutral and heat stress conditions in chickens. Most blood components changed in response to heat treatment. Mapped QTL may serve as markers for genomic selection to enhance heat tolerance in poultry and several candidate genes were identified which may give additional insight into mechanisms of physiologic response to high ambient temperatures.

\section{Methods}

Ethics statement

Animal experiments were approved by the Institutional Animal Care and Use Committee of Iowa State University: Log \#4-11-7128-G. 


\section{Chicken lines}

We used the F18 and F19 generations of an AIL between chicken lines divergent for thermotolerence created by crossing a single broiler sire to six highly inbred Fayoumi dams [67]. Birds were reared in floor pens with wood shavings bedding and had ad libitum access to water and feed that met all NRC requirements [68].

\section{Heat stress experimental design}

A total of 631 birds from four hatches (two hatches in each of the two generations) were used for independent heat stress experiments (four replicates). At 17 days of age, birds were transferred to environmentally controlled chambers and acclimated for five days. Multiple chambers, each containing 6 pens, were used per replicate. Ten to 12 birds were placed in each pen. From day 22 to 28 of age, the chambers heated to $35{ }^{\circ} \mathrm{C}$ for $7 \mathrm{~h}$ per day and remained at $25{ }^{\circ} \mathrm{C}$ at all other times.

\section{Blood variable measurements}

Blood was collected from the wing vein on day 20 (preheat) and day 28 (during heat) using a heparinized syringe and needle, and analysed immediately using an iSTAT Portable Clinical Analyser [36]. The iSTAT CG8+ cartridge was utilized to measure thirteen blood variables including; $\mathrm{pH}, \mathrm{pCO}_{2}, \mathrm{pO}_{2}$, base excess, $\mathrm{HCO}_{3}$, $\mathrm{TCO}_{2}, \mathrm{~K}, \mathrm{Na}$, ionized $\mathrm{Ca}$, hematocrit, hemoglobin, $\mathrm{sO}_{2}$, and glucose.

\section{DNA isolation and genotyping}

Blood was collected from the wing vein by using an EDTA-coated syringe and needle, and stored at $-20{ }^{\circ} \mathrm{C}$. DNA was extracted using a salting out method. Briefly, whole blood was incubated with lysis buffer containing proteinase K. Proteins were precipitated out using $5 \mathrm{M}$ $\mathrm{NaCl}$ while the supernatant remained. The supernatant was combined with $70 \%$ ethanol to precipitate out DNA. The DNA isolated from 468 AIL, 6 broiler, and 6 Fayoumi chickens was genotyped on the Affymetrix $600 \mathrm{~K}$ chicken SNP axiom array [69] by GeneSeek Inc., Lincoln, NE. SNP chromosomal locations were based on the Gallus_gallus_4.0 assembly through Ensembl.

\section{Statistical analyses}

Calculations of means and standard errors, fixed effects and covariates for the GWAS were calculated based on ANOVA (analysis of variance), and significant terms were fit as fixed effects with a $P$ value $\leq 0.05$ using JMP statistical software [70]. Heritabilities were estimated with an animal model using ASReml software [71].

Parameters for inclusion of SNP genotypes included SNP call rate $\geq 95 \%$ and minor allele frequency $\geq 5 \%$. Genotyping console (Affymetrix) software was used to create genotyping calls and quality control based on whole animal DishQC score $\geq 0.7$. The SNPolisher (Affymetrix) R package was used for quality control of individual SNP in all animals with passing DishQC scores.

The GWAS of phenotypic traits with SNP genotypes was done using GenSel software [72]. Bayes B, which fits all SNPs simultaneously as random effects, was used for the analysis. The mixed model used for the GWAS:

$$
y=X b+\sum_{j}^{k} z_{j} \alpha_{j} \delta_{j}+\varepsilon
$$

Where $\mathbf{y}=$ vector form of phenotypes, $\mathbf{X}=$ incidence matrix to account for fixed effects on phenotypes, $\mathbf{b}=$ vector of fixed effects, $\mathbf{z}_{\mathbf{j}}=$ vector of genotypes for SNP $\mathbf{j}$ based on the number of B alleles $(-10,0,+10$, or the average of the genotypes at SNP $\mathbf{j}), \alpha_{\mathbf{j}}=$ allele substitution effect for SNP $\mathbf{j}, \delta_{\mathbf{j}}=$ whether SNP $\mathbf{j}$ was included in the Markov chain Monte Carlo (MCMC) chain, and $\varepsilon$ is the error associated with the analysis.

The genomic markers were split into 1001 nonoverlapping $1 \mathrm{Mb}$ windows across the genome. A total of 41,000 MCMC iterations were run for each analysis and the first 1000 iterations were discarded (burn in). The $\delta_{j}$ was set so that $\pi=0.9978$ to avoid fitting more SNPs than number of animals in a given iteration. In a true infinitesimal model, each window is expected to explain $0.1 \%(100 \% / 1001)$ of the genetic variation; therefore, a $1 \mathrm{Mb}$ window was considered significant if it explained $\geq 0.5 \%$ of the total genetic variation, corresponding to 5 times more observed than expected.

\section{Pathway analysis}

To further investigate QTL regions, we conducted a pathway analysis using Ingenuity Pathway Analysis (IPA) software. All annotated genes within significant (explaining $\geq 0.05 \%$ of the genetic variation) $1 \mathrm{Mb}$ windows for any measured trait were identified using Ensemble biomart. This gene list was used as input into IPA and a core analysis was completed using default parameters to identify significant $(P \leq 0.05)$ canonical pathways and the top 20 significant pathways were reported. Additionally, a gene list was created using the regions of QTL co-localization (3 or more traits) and analysed as described for all QTL regions.

\section{Candidate genes}

Candidate genes were identified for regions of QTL colocalization (3 or more traits). All genes within the region were identified using ENSEMBL biomart [73]. 


\section{Syntenic regions between chicken and swine}

To identify syntenic regions for reported QTL for the same blood chemistry component measurements between chicken and pig, the Comparative Genomics option was used in Ensembl [73].

\section{Availability of Data and Materials}

The dataset supporting the conclusions of this article is available in the Animal QTLdb (animalgenome.org) repository and can be found at http://www.animalgenome.org/ cgi-bin/QTLdb/GG/pubtails?PUBMED_ID=ISU0082. The phenotypic dataset supporting the conclusions of this article is included within the article as an additional file (Additional file 2: Table S2).

\section{Additional files}

Additional file 1: Table S1. Positional candidate genes categorized by location for co-localized QTL. (DOCX $31 \mathrm{~kb}$ )

Additional file 2: Phenotypic data for blood chemistry components in 468 advanced intercross line chickens. (XLSX 123 kb)

\section{Abbreviations}

AlL: advanced intercross line; GWAS: genome wide association study; QTL: quantitative trait loci.

\section{Competing interests}

The authors have no competing interests.

\section{Authors' contributions}

AVG participated in sample collection, carried out all statistical analyses and drafted the manuscript. CMA and MEP participated in the design of the study, sample collection and acquisition of funding. MFR and CJS participated in the design of the study and acquisition of funding. SJL participated in the design of the study, participated in sample collection, participated in acquisition of funding and helped to draft the manuscript. All authors read and approved the final manuscript.

\section{Acknowledgements}

The authors thank the lowa State University Poultry Research Center staff for animal care; the Lamont, Persia, Rothschild and Ashwell lab personnel for assistance; Jack Dekkers, Dorian Garrick, Rohan Fernando and their research groups for GWAS advice; Melanie Hess and Andrew Hess for statistical and coding advice. This research was supported by USDA-NIFA-AFRI Climate Change Award \#2011-67003-30228; the USDA National Institute of Food and Agriculture, Hatch project \#5358; and AVG was partly supported by a USDA National Needs Fellowship, Award \#2011-38420-20050.

\section{Author details}

'Department of Animal Science, lowa State University, Ames, IA, USA. ${ }^{2}$ Department of Poultry Science, North Carolina State University, Raleigh, NC, USA. ${ }^{3}$ Department of Animal and Poultry Sciences, Virginia Polytechnic Institute and State University, Blacksburg, VA, USA. ${ }^{4}$ Department of Animal and Food Sciences, University of Delaware, Newark, DE, USA.

Received: 26 January 2016 Accepted: 22 March 2016

Published online: 14 April 2016

\section{References}

1. USDA. Climate Change Science White Paper. 2012.

2. St-Pierre N, Cobanov B, Schnitkey G. Economic losses from heat stress by US livestock industries. J Dairy Sci. 2003:86:E52-77.

3. Administration NOaA. Summer of 1995 heat wave. Online. 1995

4. Wolfenson D, Frei YF, Snapir N, Berman A. Heat stress effects on capillary blood flow and its redistribution in the laying hen. Pflugers Arch. 1981;390(1):86-93.
5. Yahav S, Straschnow A, Plavnik I, Hurwitz S. Blood system response of chickens to changes in environmental temperature. Poult Sci. 1997;76(4):627-33.

6. Borges S, Da Silva AF, Majorka A, Hooge D, Cummings K. Physiological responses of broiler chickens to heat stress and dietary electrolyte balance (sodium plus potassium minus chloride, milliequivalents per kilogram). Poult Sci. 2004;83(9):1551-8.

7. Garriga C, Hunter RR, Amat C, Planas JM, Mitchell MA, Moretó M. Heat stress increases apical glucose transport in the chicken jejunum. Am J Physiol Regul Integr Comp Physiol. 2006;290(1):R195-201.

8. Austic R. Feeding poultry in hot and cold climates. 1985.

9. Lin H, Malheiros R, Moraes V, Careghi C, Decuypere E, Buyse J. Acclimation of broiler chickens to chronic high environmental temperature. Archiv Fur Geflugelkunde. 2004;39:46.

10. Teeter R, Smith M, Owens F, Arp S, Sangiah S, Breazile J. Chronic heat stress and respiratory alkalosis: occurrence and treatment in broiler chicks. Poult Sci. 1985;64(6):1060-4.

11. Galla JH. Metabolic alkalosis. J Am Soc Neph. 2000;11(2):369-75.

12. Borges S, Fischer Da Silva A, Maiorka A. Acid-base balance in broilers. World Poult Sci J. 2007;63(01):73-81.

13. Borges S, Da Silva AF, Ariki J, Hooge D, Cummings K. Dietary electrolyte balance for broiler chickens exposed to thermoneutral or heat-stress environments. Poult Sci. 2003;82(3):428-35.

14. Schaal T, Arango J, Wolc A, Brady J, Fulton J, Rubinoff I, et al. Commercial Hy-Line W-36 pullet and laying hen venous blood gas and chemistry profiles utilizing the portable i-STAT ${ }^{\circledR} 1$ analyzer. Poult Sci. 2015;95:pev350.

15. Nadaf J, Pitel F, Gilbert H, Duclos MJ, Vignoles F, Beaumont C, et al. QTL for several metabolic traits map to loci controlling growth and body composition in an F2 intercross between high-and low-growth chicken lines. Physiol Gen. 2009;38(3):241-9.

16. Park H-B, Jacobsson L, Wahlberg P, Siegel PB, Andersson L. QTL analysis of body composition and metabolic traits in an intercross between chicken lines divergently selected for growth. Physiol Gen. 2006;25(2):216-23.

17. Jacobsson L, Park H-B, Wahlberg P, Fredriksson R, Perez-Enciso M, Siegel PB, et al. Many QTLs with minor additive effects are associated with a large difference in growth between two selection lines in chickens. Genet Res. 2005;86(02):115-25.

18. Zhou H, Evock-Clover C, McMurtry J, Ashwell C, Lamont S. Genome-wide linkage analysis to identify chromosomal regions affecting phenotypic traits in the chicken. IV. Metabolic traits. Poult Sci. 2007:86(2):267-76.

19. Martin MP, Wineland M, Barnes HJ. Selected blood chemistry and gas reference ranges for broiler breeders using the $\mathrm{i}-\mathrm{STAT}^{\circledR}$ handheld clinical analyzer. Avian Dis. 2010;54(3):1016-20.

20. Deeb N, Lamont S. Use of a novel outbred by inbred F1 cross to detect genetic markers for growth. An Genet. 2003;34(3):205-12.

21. Li H, Deeb N, Zhou H, Mitchell A, Ashwell C, Lamont S. Chicken quantitative trait loci for growth and body composition associated with transforming growth factor-beta genes. Poult Sci. 2003;82(3):347-56.

22. Zhou H, Deeb N, Evock-Clover C, Ashwell C, Lamont S. Genome-wide linkage analysis to identify chromosomal regions affecting phenotypic traits in the chicken. I. Growth and average daily gain. Poult Sci. 2006;85(10):1700-11.

23. Zhou H, Deeb N, Evock-Clover C, Ashwell C, Lamont S. Genome-wide linkage analysis to identify chromosomal regions affecting phenotypic traits in the chicken. II. Body composition. Poult Sci. 2006;85(10):1712-21.

24. Abasht B, Lamont S. Genome-wide association analysis reveals cryptic alleles as an important factor in heterosis for fatness in chicken F2 population. An Genet. 2007;38(5):491-8.

25. Zhou H, Deeb N, Evock-Clover C, Mitchell A, Ashwell C, Lamont S. Genomewide linkage analysis to identify chromosomal regions affecting phenotypic traits in the chicken. III. Skeletal integrity. Poult Sci. 2007:86(2):255-66.

26. Kaiser M, Lamont S. Microsatellites linked to Salmonella enterica Serovar Enteritidis burden in spleen and cecal content of young F1 broiler-cross chicks. Poult Sci. 2002;81(5):657-63.

27. Kaiser M, Deeb N, Lamont S. Microsatellite markers linked to Salmonella enterica serovar enteritidis vaccine response in young F1 broiler-cross chicks. Poult Sci. 2002;81(2):193-201.

28. Liu W, Lamont S. Candidate Gene Approach: Potentional Association of Caspase-1, Inhibitor of Apoptosis Protein-1, and Prosaposin Gene Polymorphisms with Response to Salmonella enteritidis Challenge or Vaccination in Young Chicks. An Biotech. 2003;14(1):61-76.

29. Van Goor A, Bolek KJ, Ashwell CM, Persia ME, Rothschild MF, Schmidt CJ, et al. Identification of quantitative trait loci for body temperature, body 
weight, breast yield, and digestibility in an advanced intercross line of chickens under heat stress. Genet Sel Evol. 2015;47(1):1-13.

30. Randall W, Hiestand W. Panting and temperature regulation in the chicken Am J Physiol. 1939:127(4):761-7.

31. Sandercock D, Hunter R, Nute G, Mitchell M, Hocking P. Acute heat stressinduced alterations in blood acid-base status and skeletal muscle membrane integrity in broiler chickens at two ages: Implications for meat quality. Poult Sci. 2001;80(4):418-25.

32. Deyhim F, Teeter R. Research note: sodium and potassium chloride drinking water supplementation effects on acid-base balance and plasma corticosterone in broilers reared in thermoneutral and heat-distressed environments. Poult Sci. 1991;70(12):2551-3.

33. Closter A, Van As P, Groenen M, Vereijken A, Van Arendonk J, Bovenhuis H. Genetic and phenotypic relationships between blood gas parameters and ascites-related traits in broilers. Poult Sci. 2009;88(3):483-90.

34. Daghir N. Nutrient requirements of poultry at high temperature. Poultry production in hot climate. 2008;133:60.

35. Guoa X, Huanga K, Chenga H, Luo J, Pana C. High dietary calcium causes metabolic alkalosis in growing layers. Poult Sci. 2008;87(7):1353-7.

36. Chin CD, Linder V, Sia SK. Commercialization of microfluidic point-of-care diagnostic devices. Lab Chip. 2012;12(12):2118-34.

37. Halley J, Nelson T, Kirby L, Johnson Z. Effect of altering dietary mineral balance on growth, leg abnormalities, and blood base excess in broiler chicks. Poult Sci. 1987;66(10):1684-92.

38. Ait-Boulahsen A, Garlich J, Edens F. Effect of fasting and acute heat stress on body temperature, blood acid-base and electrolyte status in chickens. Comp Biochem Physiol. 1989;94(4):683-7.

39. Meyer TE, Verwoert GC, Hwang S-J, Glazer NL, Smith AV, Van Rooij F, et al. Genome-wide association studies of serum magnesium, potassium, and sodium concentrations identify six loci influencing serum magnesium levels. PLoS Genet. 2010;6(8), e1001045.

40. Tordoff MG, Bachmanov AA, Reed DR. Forty mouse strain survey of voluntary calcium intake, blood calcium, and bone mineral content. Physiol Behav. 2007;91(5):632-43.

41. Reiner G, Fischer R, Köhler F, Berge T, Hepp S, Willems H. Heritabilities and quantitative trait loci for blood gases and blood $\mathrm{pH}$ in swine. An Genet 2009;40(2):142-8.

42. Washburn K. Heritability of packed red blood cell volume in the domestic fowl. Poult Sci. 1967;46(4):1025-6.

43. Boschiero C, Jorge EC, Ninov K, Nones K, Do Rosário MF, Coutinho LL, et al. Association of IGF1 and KDM5A polymorphisms with performance, fatness and carcass traits in chickens. J Appl Genet. 2013;54(1):103-12.

44. Der Laan M-H P-V, Bed'Hom B, Coville J-L, Pitel F, Feve K, Leroux S, et al. Microsatellite mapping of QTLs affecting resistance to coccidiosis (Eimeria tenella) in a Fayoumi $\times$ White Leghorn cross. BMC Genomics. 2009;10(1):31.

45. Navarro P, Visscher P, Knott S, Burt D, Hocking P, Haley C. Mapping of quantitative trait loci affecting organ weights and blood variables in a broiler layer cross. Brit Poult Sci. 2005;46(4):430-42.

46. Ewald S, Ye X, Avendano S, McLeod S, Lamont S, Dekkers J. Associations of BF2 alleles with antibody titres and production traits in commercial pure line broiler chickens. An Genet. 2007:38(2):174-6.

47. Khan W, Khan A, Anjuman A, Rehman Z. Effects of induced heat stress on some biochemical values in broiler chicks. Int J Agric Biol. 2002;4:74-5.

48. Leclercq B, Simon J, Ricard F. Effects of selection for high and low plasma glucose concentration in chickens. Brit Poult Sci. 1987;28(4):557-65.

49. Demeure O, Duclos MJ, Bacciu N, Le Mignon G, Filangi O, Pitel F, et al. Genome-wide interval mapping using SNPs identifies new QTL for growth, body composition and several physiological variables in an F2 intercross between fat and lean chicken lines. Genet Sel Evol. 2013;45:36.

50. Mihaylova MM, Shaw RJ. The AMPK signalling pathway coordinates cell growth, autophagy and metabolism. Nat Cell Biol. 2011;13(9):1016-23.

51. Glover JR, Lindquist S. Hsp104, Hsp70, and Hsp40: a novel chaperone system that rescues previously aggregated proteins. Cell. 1998;94(1):73-82.

52. Dostrovsky N, Towheed T, Hudson R, Anastassiades T. The effect of glucosamine on glucose metabolism in humans: a systematic review of the literature. Osteoarth Cart. 2011;19(4):375-80.

53. Nassar M, Goraga Z, Brockmann G. Quantitative trait loci segregating in crosses between New Hampshire and White Leghorn chicken lines: IV. Growth performance. An Genet. 2015.

54. Ambo M, Moura A, Ledur M, Pinto L, Baron E, Ruy D, et al. Quantitative trait loci for performance traits in a broiler $\times$ layer cross. An Genet. 2009;40(2):200-8.
55. Zhou Y, Liu Y, Jiang X, Du H, Li X, Zhu Q. Polymorphism of chicken myocyte-specific enhancer-binding factor 2A gene and its association with chicken carcass traits. Molec Biol Rep. 2010;37(1):587-94.

56. Campos R, Nones K, Ledur M, Moura A, Pinto L, Ambo M, et al. Quantitative trait loci associated with fatness in a broiler-layer cross. An Genet. 2009; 40(5):729-36.

57. Buitenhuis A, Rodenburg T, Siwek M, Cornelissen S, Nieuwland M, Crooijmans $\mathrm{R}$, et al. Identification of QTLs involved in open-field behavior in young and adult laying hens. Behav Genet. 2004;34(3):325-33.

58. Renehan AG, Zwahlen M, Minder CT, O'Dwyer S, Shalet SM, Egger M. Insulin-like growth factor (IGF)-I, IGF binding protein-3, and cancer risk: systematic review and meta-regression analysis. Lancet. 2004;363(9418): 1346-53.

59. Schreiweis $M$, Hester $P$, Settar $P$, Moody $D$. Identification of quantitative trait loci associated with egg quality, egg production, and body weight in an F2 resource population of chickens1. An Genet. 2006;37(2):106-12.

60. Rabie T, Crooijmans R, Bovenhuis H, Vereijken A, Veenendaal T, Poel JD, et al. Genetic mapping of quantitative trait loci affecting susceptibility in chicken to develop pulmonary hypertension syndrome. An Genet. 2005; 36(6):468-76.

61. Sun $Y$, Biscarini F, Bovenhuis $H$, Parmentier $H$, Poel VDJ. Genetic parameters and across-line SNP associations differ for natural antibody isotypes lgM and IgG in laying hens. An Genet. 2013;44(4):413-24.

62. Mashaly M, Hendricks G, Kalama M, Gehad A, Abbas A, Patterson P. Effect of heat stress on production parameters and immune responses of commercial laying hens. Poult Sci. 2004;83(6):889-94.

63. Kültz D. Molecular and evolutionary basis of the cellular stress response. Annu Rev Physiol. 2005;67:225-57.

64. Hosseini-Vashan S, Golian A, Yaghobfar A. Growth, immune, antioxidant, and bone responses of heat stress-exposed broilers fed diets supplemented with tomato pomace. Int J Biomet. 2015;1:10.

65. Chen W, Melamed ML, Abramowitz MK. Serum bicarbonate and bone mineral density in US adults. Am J Kid Dis. 2015;65(2):240-8.

66. Reiner G, Clemens N, Fischer R, Köhler F, Berge T, Hepp S, et al. Mapping of quantitative trait loci for clinical-chemical traits in swine. An Genet. 2009; 40(1):57-64

67. Deeb N, Lamont S. Genetic architecture of growth and body composition in unique chicken populations. J Hered. 2002;93(2):107-18.

68. NRC. Nut Requ Poult. National Research Council. USA: National Academy Press Washington; 1994

69. Kranis A, Gheyas AA, Boschiero C, Turner F, Yu L, Smith S, et al. Development of a high density 600 K SNP genotyping array for chicken. BMC Genomics. 2013;14(1):59.

70. Institute S. JMP statistical discovery software. 2000.

71. Gilmour AR, Gogel B, Cullis B, Thompson R, Butler D. ASReml user guide release 3.0. VSN Int Ltd. 2009.

72. Fernando R, Garrick D. GenSel user manual for a portfolio of genomic selection related analyses. Ames: Animal Breeding and Genetics, lowa State University; 2008

73. Cunningham F, Amode MR, Barrell D, Beal K, Billis K, Brent S, et al. Ensembl 2015. Nucleic Acids Res. 2015;43(D1):D662-9.

\section{Submit your next manuscript to BioMed Central and we will help you at every step:}

- We accept pre-submission inquiries

- Our selector tool helps you to find the most relevant journal

- We provide round the clock customer support

- Convenient online submission

- Thorough peer review

- Inclusion in PubMed and all major indexing services

- Maximum visibility for your research

Submit your manuscript at www.biomedcentral.com/submit 